\title{
Disrupted tight junctions in the small intestine of cystic fibrosis mice
}

\author{
Robert C. De Lisle \\ University of Kansas School of Medicine, Anatomy \& Cell Biology, MS 3038, 3901 Rainbow Blvd., \\ Kansas City, KS 66160
}

\begin{abstract}
The tight junction (TJ) is the major determinant of paracellular permeability, which in the gut protects the body from entry of harmful substances such as microbial components. In cystic fibrosis (CF) there is increased permeability of the small intestine both in humans and in CF mice. To gain insight into the mechanisms of increased intestinal permeability in CF, I analyzed the composition of the $\mathrm{TJ}$ in the cystic fibrosis transmembrane conductance regulator $(\mathrm{Cftr})$ knockout mouse model. Significant changes in TJ gene expression in the CF intestine were found for Cldnl, $C l d n 7, C l d n 8$, and Pmp22 which were expressed at lower levels; and Cldn2 which was expressed at a higher level. Protein levels of claudin- 2 were increased in the $\mathrm{CF}$ intestine as compared to wild type, while other TJ proteins were not significantly different. In the villus epithelium of the $\mathrm{CF}$ intestine, all $\mathrm{TJ}$ components analyzed were mislocalized to the basal cytoplasm and showed varying degrees of loss from the TJ and apico-lateral surfaces. The pore-forming claudin-2 in the $\mathrm{CF}$ intestine showed more intense staining but was correctly localized to the TJ, principally in the crypts which are enlarged in CF. The cytokine TNFa, known to affect TJ, was elevated to $160 \%$ of wild type in the CF intestine. In summary, there is a dramatic redistribution of claudin proteins from the TJ/lateral membrane to the basal cytoplasm of the villus epithelium in the CF intestine. These changes in TJ protein localization in $\mathrm{CF}$ are likely to be involved in the increased permeability of the CF small intestine to macromolecules, and TNFa may be a causative factor.
\end{abstract}

\section{Introduction}

In the autosomal recessive genetic disease cystic fibrosis (CF), the small intestine is affected in numerous ways which contribute to impaired nutrition (De Lisle and Borowitz 2013) which in turn affects the decline in airway function that is lethal in this disease (Stallings et al. 2008). The CF gene product, the cystic fibrosis transmembrane conductance regulator (CFTR), is a cAMP regulated anion channel required for adequate $\mathrm{NaCl} /$ fluid and bicarbonate secretion. Loss of CFTR function results in an acidic poorly-hydrated intestinal environment (De Lisle and Borowitz 2013). This is believed to cause accumulation of mucus in the intestine which becomes colonized and overgrown by bacteria and leads to an inflammatory response (Norkina et al. 2004a;De Lisle and Borowitz 2013).

The epithelium of the small intestine is a single cell layer thick, and is the key structure that separates the intestinal lumen from the body proper. This epithelium is a selective barrier that mediates uptake of digested nutrients but normally excludes bacteria and their inflammatory components (e.g., lipopolysaccharide) (Camilleri et al. 2012). Specific transporters in the enterocyte plasma membrane accomplish nutrient uptake and electrolyte transport across the epithelium (e.g., $\mathrm{Na}$--coupled solute absorption, $\mathrm{NaCl}$ secretion and

Contact. Robert C. De Lisle, PhD, Anatomy \& Cell Biology, MS 3038, 3901 Rainbow Blvd, University of Kansas School of Medicine, Kansas City, KS 66160, phone 913-588-2742, fax 913-588-2710, redlisle @ kumc.edu. 
absorption) (Drozdowski and Thomson 2006), whereas the paracellular pathway between neighboring epithelial cells is a selective barrier controlling passage of macromolecules (e.g., bacterial products) as well as electrolytes (especially $\mathrm{Na}+$ ) (Anderson and Van Itallie 2009).

The tight junction ( $\mathrm{TJ}$ or zonula occludens) is the major structural barrier to passage of materials through the paracellular pathway (Anderson and Van Itallie 2009). Properties of the $\mathrm{TJ}$ are characteristic of specific epithelia and reflect their particular functions. In the small intestine, the epithelium has a relatively low electrical resistance (Markov et al. 2010) which is probably involved in the small intestine's nutrient absorptive functions (Wada et al. 2012). The components of the tight junction are numerous, including occludin, tricellulin (enriched at tricellular junctions and encoded by the Marveld2 gene) (Ikenouchi et al. 2005), the junctional adhesion molecule (JAM) proteins (Laukoetter et al. 2007), and the large claudin family of which there are 24-27 members in mammalian genomes (Gunzel and Yu 2013). The claudins are the major determinant of electrolyte permeability through the paracellular pathway (Gunzel and Yu 2013). Increased macromolecule permeability is suggested to be caused by disruption of the TJ structure (Anderson and Van Itallie 2009). An alternative hypothesis is that the tricellular junction where three epithelial cells meet is the major route of macromolecule permeation, and that modulation of this junction controls such passage (Krug et al. 2009) with a central role for the junctional protein tricellulin (Ikenouchi et al. 2005).

The TJ is dynamic and alterations in its composition can increase permeability of the epithelium and thus regulate paracellular passage of electrolytes and macromolecules. Such changes can be acute, such as occur during intestinal absorption of monosaccharides (Berglund et al. 2001) or more chronic such as occur in pathological states like inflammatory bowel disease (Lameris et al. 2013;Suzuki et al. 2011). In general, inflammation of the intestine causes increased permeability to macromolecules through the paracellular pathway (John et al. 2011). This is controlled by several cytokines (Suzuki et al. 2011;Al-Sadi et al. 2011;Mashukova et al. 2011;Beaurepaire et al. 2009) as well as by bacterial proteins, including some enterotoxins, which affect the cytoskeleton or components of the TJ (Guttman and Finlay 2009;Camilleri et al. 2012;Takahashi et al. 2005). Changes associated with increased permeability include altered expression of $\mathrm{TJ}$ component genes (Lameris et al. 2013), often accompanied by altered levels of TJ proteins (Zeissig et al. 2007) internalization of some proteins away from the TJ (Bruewer et al. 2003).

Patients with CF exhibit intestinal inflammation (De Lisle and Borowitz 2013; Werlin et al. 2010), and intestinal permeability is also increased (Hallberg et al. 1997; van Elburg et al. 1996). My lab has shown that increased intestinal permeability also occurs in the widely used mouse model of CF, the Cftr knockout mouse (CF mouse) (De Lisle et al. 2011). These mice have bacterial overgrowth (Norkina et al. 2004a) and a mild inflammation (Norkina et al. 2004b). We observed increased serum albumin (66 kDa) in the CF mouse intestinal lumen, and increased concentrations of fluorescent dextran in the blood after gavage into the gastrointestinal tract of CF mice, as compared to wild type mice (De Lisle et al. 2011). The relative increase in fluorescence in the blood of $\mathrm{CF}$ as compared to wild type mice was greater using a large $(70 \mathrm{kDa})$ vs. small $(4 \mathrm{kDa})$ dextran, consistent with altered paracellular permeability rather than transcellular transport (Watson et al. 2001). To gain insight into the mechanisms of increased intestinal macromolecule permeability in CF, I investigated the expression at mRNA and protein levels, and localization of components of the $\mathrm{TJ}$ in the $\mathrm{CF}$ mouse small intestine. 


\section{Materials and Methods}

\section{Mice}

Mice heterozygous for a targeted null mutation in the $C f t r$ gene $\left(C f t{ }^{t m 1 U N C}\right.$; originally obtained from Jackson Labs, Bar Harbor, ME) (Snouwaert et al. 1992) congenic on the C57BL/6J background (generation 32) were bred to obtain Cftr null (CF) and wild type (WT) mice. Genotyping was by tail snip DNA according to the protocol from Jackson Labs (www.jax.org). All mice, including WT, were fed a liquid diet to prevent lethal intestinal obstruction in CF mice (Eckman et al. 1995). Mice were killed between 6-12 weeks of age and both genders were used.

\section{qRT-PCR}

Total RNA was isolated from the entire small intestine using TRIzol reagent (www.invitrogen.com). Approximately $5 \mathrm{ng}$ of total RNA was used as template for a SYBR green based one-tube quantitative reverse transcription polymerase chain reaction (qRTPCR) (www.qiagen.com) in a Bio-Rad iCycler (www.bio-rad.com). The housekeeping gene ribosomal protein L26 (Rpl26) was used for normalization, the $\Delta \Delta \mathrm{C}_{\mathrm{t}}$ method with correction for differential PCR efficiencies was used (28), and CF values are presented relative to WT values set to unity. Primers used are given in the Table. All primer pairs were tested by serial dilution to determine PCR efficiency, and expected product size was verified by agarose gel electrophoresis.

\section{Western blot}

Intestinal tissue was homogenized in $10 \mathrm{mM}$ Tris, $\mathrm{pH} 7.0$ plus HALT protease inhibitors (www.pierce.com) at a ratio of $10 \mathrm{~mL} / \mathrm{gram}$ tissue. Intestinal proteins were separated on SDS-PAGE and transferred to PVDF membranes. The DNA concentration of the tissue homogenates, as determined using a fluorometric assay for DNA (Cesarone et al. 1979), was used to load equal amounts of samples. Blots were blocked in 5\% dry milk solution, probed with the indicated primary antibody followed by an alkaline phosphatase secondary antibody, and color developed using 5-bromo-4-chloro-3-indolyl phosphate and nitroblue tetrazolium. The blots were then reprobed for $\beta$-actin. Developed blots were dried and scanned with an HP (www.hp.com) flatbed scanner and intensities quantified using Optiquant software (Kodak, Rochester, NY). The staining intensity of each specific antibody was normalized to that for $\beta$-actin. The antibodies used were against: occludin (www.invitrogen.com, \#71-1500), claudin-1 (www.abcam.com, \#ab15098), claudin-2 (www.bioworlde.com, \#BS1066), claudin-3 (www.invitrogen.com, \#34-1700), claudin-5 (www.millipore.com, \#ABT45), claudin-7 (www.invitrogen.com, \#34-9100), claudin-8 (www.invitrogen.com, \#40-0700), claudin-15 (www.invitrogen.com, \#38-9200), and $\beta$ actin (www.sigmaaldrich.com, \#A-2066). It should be noted that the antibodies against claudin- 1 and claudin- 3 were both raised against $\mathrm{C}$-terminal domains and these two claudins share the last four amino acids. Therefore, there could be some cross-reactivity between these antibodies and the other claudin. An antibody against claudin-1 certified to not be claudin-3 cross-reactive (www.invitrogen.com, \#51-900) did not work for Western blot of mouse intestine (data not shown). Similarly, the antibody to claudin-5 could also cross-react with the related claudin-6, however, the mRNA abundance of $C l d n 5$ is about 80-fold greater than that for $C l d n 6$, as based on comparing $\mathrm{C}_{\mathrm{t}}$ values from the qRT-PCR analysis (Table).

\section{Indirect immunofluorescence}

Intestinal samples from the proximal ileum ( $70 \%$ of the distance from the stomach to cecum) were fixed in $4 \%$ formaldehyde freshly prepared from paraformaldehyde, cryoprotected in a graded sucrose series (Barthel and Raymond 1990), and cryosections 
were prepared and collected on gelatin chrome-alum coated slides. Primary antibodies (see above) were diluted in $2 \%$ normal donkey serum and applied for $1 \mathrm{hr}$ at $37^{\circ} \mathrm{C}$, followed by donkey FITC conjugated secondary antibody plus 4'-6-diamidino-2-phenylindole (DAPI) to label nuclei and Texas Red-phalloidin to label the cortical F-actin cytoskeleton. Images were obtained using a SPOT II digital camera (http://www.spotimaging.com) on a Nikon Eclipse TE300 fluorescence microscope (www.nikoninstruments.com).

\section{Cytokine assay}

Intestinal samples were homogenized in T-Per solution plus HALT protease inhibitors (www.pierce.com). Protein concentrations were determined using a micro-BCA assay (www.pierce.com). Cytokines were measured using a Luminex assay, performed by the Inflammatory Mediator Core laboratory at Case Western Reserve University (http:// cf.case.edu/cores.html).

\section{Statistics}

Data are presented as means \pm standard error of the means. Values were compared by t-test and $P<0.05$ considered significant.

\section{Results}

As an initial step to analyze $\mathrm{TJ}$ in the $\mathrm{CF}$ mouse small intestine, I interrogated our previously published transcriptome analysis of CF compared to wild (WT) mouse small intestine (dataset GSE765 at http://www.ncbi.nlm.nih.gov/gds) (Norkina et al. 2004b) for tight junction genes. In the microarray data of the CF intestine compared to WT, there was a significant decrease in expression of $\mathrm{Cldn} 8$, which is expressed in the ileum (Fujita et al. 2006) and is a barrier-forming claudin (Amasheh et al. 2009); a decrease in the claudin family member peripheral myelin protein 22 (Pmp22), which is best known for its role in demyelinating neuropathies but is also a component of epithelial TJs (Notterpek et al. 2001) and affects paracellular permeability, growth, and migration of epithelial cells (Roux et al. 2005); and a significant increase in expression of claudin-2 (Cldn2), which is a Na+selective pore forming claudin (Amasheh et al. 2002) that is often upregulated in intestinal inflammation (Denizot et al. 2012).

In addition to the genes changed on the microarrays of the CF small intestine, other common $\mathrm{TJ}$ components and those that have been reported to be altered in intestinal disease states were analyzed by qRT-PCR to compare expression levels in WT and CF mouse small intestine. These mRNAs include Cldn1, whose expression is increased in intestinal cell culture by TNFa, and which was associated with increased paracellular permeability (Poritz et al. 2011); Cldn3, whose expression is associated with decreased permeability of the intestine during postnatal maturation (Patel et al. 2012), decreased permeability when transfected into a kidney cell line (Milatz et al. 2010), and is also a target of Clostridium perfringens enterotoxin (Takahashi et al. 2005), a bacterium that is increased in the CF mouse small intestine (Norkina et al. 2004a); Cldn4, another target of C.perfringens enterotoxin (Takahashi et al. 2005); Cldn5, which is downregulated and lost from TJs in Crohn's inflammatory bowel disease (Zeissig et al. 2007); Cldn6, which is a barrier-forming claudin associated with decreased cation permeability (Gunzel and Yu 2013); Cldn7, which is strongly expressed in the gastrointestinal tract (Fujita et al. 2006) and in Cldn7 deficient mice there is disruption of the mucosa and inflammation (Ding et al. 2012); Cldn10, a poreforming claudin (Gunzel and Yu 2013); Cldn15, which along with Cldn2, is crucial in supplying $\mathrm{Na}+$ to the intestinal lumen to support $\mathrm{Na}+$-dependent nutrient uptake in the small intestine (Tamura et al. 2008; Wada et al. 2012); tricellulin (Marveld2 gene), which is the most abundant component of tricellular junctions which are proposed to have a major role in 
paracellular macromolecule permeability (Krug et al. 2009;Ikenouchi et al. 2005); Ocln, the earliest discovered TJ transmembrane protein (Furuse et al. 1993); and Tjp1, which encodes zonula occludens 1 (ZO-1), an adaptor connecting transmembrane TJ proteins to the actin cytoskeleton (Fanning et al. 1998; Stevenson et al. 1986). The primers used and the $\mathrm{C}_{\mathrm{t}}$ values obtained for each using the same amount of input total RNA from a WT intestine sample, as an estimate of relative transcript abundances, are listed in the Table.

qRT-PCR analysis confirmed significantly increased Cldn2 mRNA levels (Fig. 1b; $P=0.005$ ) and significantly decreased $C l d n 8$ (Fig. $1 \mathrm{~h} ; P=0.0009$ ) and Pmp22 (Fig. 1m; $P=0.0028)$ mRNA levels. In addition by qRT-PCR, there also was significantly less claudin-1 (Cldnl) expression (Fig. 1a; $P=0.005$ ); $C l d n 1$ was represented on the microarrays but the signal strength was very low and the 'call' from the GCOS software (www.affymetrix.com) was 'Absent', suggesting the probe set on the microarray was not optimal for this mRNA. Also by qRT-PCR, there was a significant decrease of $\sim 30 \%$ in $C l d n 7$ (Fig. 1g; $P=0.0077$ ) expression, but no changes in mRNA levels of $C l d n 3$ (Fig. 1c; $P=0.658$ ), $C \ln d 4$ (Fig. 1d; $P=0.562$ ), $C \operatorname{lnd5}$ (Fig. 1e; $P=0.693$ ), $C l d n 6$ (Fig. 1f; $P=0.245$ ), Cldn10 (Fig. 1i; 0.137), Cldn15 (Fig. 1j; $P=0.065$ ), tricellulin (Fig. 1k; $P=0.186$ ), occludin (Ocln; Fig. 11; $P=0.481$ ), or zonula occludens 1 (ZO-1 or tight junction protein 1, Tjp1; Fig. $1 \mathrm{n} ; P=0.522)$.

Next, selected TJ protein levels were measured by Western blot comparing CF to WT. Preliminary studies to see where along the small intestine changes in TJ protein expression was maximal showed that the proximal ileum ( $70 \%$ of the distance from duodenum to terminal ileum) had the biggest differences comparing CF to WT intestine (not shown). Therefore, the proximal ileum of CF and WT intestines was used for subsequent analysis.

In the CF proximal ileum there was not a statistically significant difference in the amount of occludin as compared to WT (Fig. 2a, a', a"; $P=0.256$ ). In contrast, there was a marked and significant increase in claudin-2 protein in the CF proximal ileum (Fig. 2c, c', c"; $P=0.0058$ ). In contrast to the expression data, there was not a significant change in the amount of claudin-1 protein by western blot (Fig. 2b, b', b"; $P=0.337$ ), or claudin-8 (Fig. 2g, g', g"; $P=0.819$ ). Also, there were not significant differences for claudin-3 (Fig. 2d, d', d"; $P=0.337$ ), claudin-5 (Fig. 2e, e', e"; $P=0.267$ ), claudin-7 (Fig. 2f, $\mathrm{f}^{\prime}, \mathrm{f}^{\prime \prime} ; P=0.392$ ), or claudin-15 (Fig. 2h. h', h"; $P=0.342$ ). Reliable antibodies against Pmp22 could not be found, so the decrease in Pmp 22 mRNA expression in the CF intestine could not be confirmed at the protein level. Also, a good commercially available antibody to tricellulin was not identified so this TJ component also was not further analyzed in the CF intestine. With the exception of claudin-2, there were no significant changes in protein levels of $\mathrm{TJ}$ components examined. Therefore, it was important to examine the localization of TJ proteins in the $\mathrm{CF}$ intestinal epithelium.

To determine if localization of TJ components was altered in the CF small intestine, indirect immunofluorescence was used. As expected, TJ proteins in the WT proximal ileum were localized to the apico-lateral surface of the villus enterocytes (Fig. 3-4). As shown in the WT proximal ileum, claudin-1 co-localizes with the F-actin cortical cytoskeleton (stained with Texas Red phalloidin) as well as being along the lateral plasma membrane surface (Fig. $3 \mathrm{a}, \mathrm{a}^{\prime}, \mathrm{a}$ "). In contrast, in the CF proximal ileum, claudin- 1 was largely absent from the apico-lateral surface and instead there was immunoreactivity in the basal cytoplasm of villus enterocytes (Fig. 3b, b', b"). The F-actin cortical cytoskeleton was not noticeably different in the CF proximal ileum villus epithelium (Fig. 3-4). Localization of claudin-3 in the CF proximal ileum displayed some loss of apico-lateral staining (Fig. 3d, d', d") as compared to WT (Fig. 3c, c', c"), as well as accumulation in the basal portion of the enterocytes in the CF tissue (Fig. 3d, d', d"). Localization of claudin-5 was strong at the TJ region and with some 
lateral membrane staining in WT proximal ileum (Fig. 3e, e', e"). In contrast, in the CF tissue most staining for claudin-5 was in the basal cytoplasm (Fig. 3f, f', f"). Localization of claudin-7 in WT proximal ileum was mostly at the apical surface with some basal cytoplasmic staining (Fig. 4a, a', a"). In contrast to WT, in the CF ileum, there was very little apical claudin-7 localization and strong staining in the basal cytoplasm (Fig. 4b, b', b"). Claudin-8 in the WT tissue was strong at the apical surface with a little basal cytoplasm staining (Fig. 4c, c', c"), whereas localization of claudin-8 in the CF ileum was strong in the basal cytoplasm (Fig. 4d, d', d"). For occludin, in the WT tissue labeling was strong at the TJ region as well as along the apico-lateral surfaces (Fig. 4e, e', e"). In the CF proximal ileum there was still TJ labeling for occludin observed but there was less lateral membrane signal and strong basal cytoplasmic immunoreactivity (Fig. 4f, f', f"), which was distinct from the WT pattern.

In accord with previous reports (Rahner et al. 2001), claudin-2 was largely expressed in the crypt epithelium and localized mainly to the apical surface in the WT ileum (Fig. 5a, a', a"). Claudin-2 was normally localized in the CF crypts to the apical surface (Fig. 5b, b', b") but the intensity of labeling appeared greater and there was also more pronounced staining of the lateral membranes. As previously reported (Durie et al. 2004; De Lisle et al. 2007), the CF crypts were noticeably larger than in the WT tissue (Fig. 5b and a, respectively).

Finally, a Luminex multiplex enzyme immunoassay was performed on homogenates of proximal ileum to measure cytokines known to be involved in inflammation and in altered TJ function. In the CF proximal ileum there was a significant increase in TNFa (Fig. 6a; $P=0.021$ ), which is known to alter TJs and increase permeability in cultured cells (Poritz et al. 2011) and in the inflamed intestine (Mazzon and Cuzzocrea 2008). On the other hand, IFN $\gamma$, also known to increase TJ permeability (Watson et al. 2005), was significantly decreased in the CF proximal ileum (Fig. $6 \mathrm{~b} ; P=0.0047$ ). The anti-inflammatory cytokine, IL-10 which indirectly decreases TJ permeability (Sun et al. 2008;Camilleri et al. 2012), was significantly decreased in the CF proximal ileum (Fig. $6 \mathrm{c} ; P=0.0431$ ). And, there was not a significant change in IL-1 $\beta$ or IL-6 in the CF proximal ileum (Fig. $6 \mathrm{~d} ; P=0.467$ and e; $P=0.0797$, respectively).

\section{Discussion}

It is known that permeability is increased in the intestines of people with $\mathrm{CF}$ and in CF mice. It was not known what is the cause of this increased permeability. Recent wireless capsule endoscopic results show that the small intestines of most patients with CF have macroscopic evidence of inflammation (Werlin et al. 2010). Some of the observed changes included mucosal breaks and frank ulcerations, which would increase mucosal permeability, however, whether these pathologies are the sole source of increased permeability in CF is not known. Also, in the $\mathrm{CF}$ mouse, with the exception of dramatic accumulation of secreted mucus, the mucosa appears fairly normal and mucosal breaks or ulcerations have not been reported (Norkina et al. 2004b;Norkina et al. 2004a;Durie et al. 2004). Therefore, in this work I investigated whether the components of the tight junction in the CF mouse small intestine were perturbed.

The results showed that although mRNA levels of several of the analyzed TJ genes had altered expression in the CF intestine, the only change confirmed at the protein level was the strong increase in claudin-2 protein in the CF proximal ileum. Overall the Western blot data indicate that protein levels of the abundant TJ components is not altered in the CF proximal ileum, with the exception of claudin-2 which was dramatically increased. 
A TJ component whose mRNA was decreased in the CF intestine is Pmp22. Pmp22 (peripheral myelin protein 22) is a member of the PMP22/EMP/MP20/claudin, or pfam00822, superfamily (Van Itallie and Anderson 2006). PMP22 is a major component of myelin in peripheral nerve fibers, is synthesized by Schwann cells, and mutation or duplication of this gene causes demyelinating neuropathy, most notably Charcot-MarieTooth disease (Timmerman et al. 1992). Interestingly, PMP22 is also expressed in epithelia (Notterpek et al. 2001) and expression of Pmp22 in cultured kidney cells increases macromolecule permeability while at the same time increasing transepithelial resistance (Roux et al. 2005). The contrary effects of Pmp22 on macromolecule and electrolyte permeability have not been explained yet. While our microarray data and qRT-PCR show this gene is strongly expressed in the WT mouse (Table) and significantly less so in the CF mouse small intestine (Fig. 1m), we were unable to find a suitable antibody to confirm this at the protein level or to investigate whether localization of Pmp22 was altered in CF.

The most important changes observed in the CF ileum was that immunolocalization of TJ proteins in the villus epithelium showed a loss of claudins at the TJ/lateral membrane and appearance of immunoreactivity in the basal cytoplasm of the CF villus enterocytes. Occludin was correctly localized to the TJ in the CF intestine, but there was loss of lateral membrane localization and the appearance of increased basal cytoplasmic immunostaining similar to that for the various claudins investigated. These data indicate that TJs in the CF intestine are structurally abnormal with an accumulation of claudins and occludin in the cytoplasm.

The prevailing view is that the claudin composition of a tight junction creates pore-like structures that determine permeability to small $(<4 \AA)$ charged molecules, especially electrolytes (Anderson and Van Itallie 2009). Paracellular passage of macromolecules (>4Å) is proposed to occur through breaks in the structure of tight junctions (Anderson and Van Itallie 2009). Nonselective flux of larger molecules can be enhanced by cytokines without affecting the smaller pore-like pathway (Watson et al. 2005). There is also evidence that this nonselective pathway is controlled by the cytoskeleton, particularly the cortical F-actin that underlies the apical plasma membrane and is attached to the junctional complex (Fanning et al. 2012). There was no evident change in the F-actin cortical cytoskeleton in the CF mouse intestine. However, in other studies, interactions of CFTR protein with the PDZ domain protein NHERF1 has been shown to increase mucosal barrier function and this was associated with reorganization of the actin cytoskeleton in cultured airway cells (Castellani et al. 2012). Therefore, analysis of PDZ domain proteins (Rodgers et al. 2013) that link the $\mathrm{TJ}$ to the cytoskeleton deserves further attention in the future.

An alternative hypothesis to the idea that disruption of the tight junctions between two adjacent epithelial cells (bicellular junctions) is responsible for paracellular macromolecule permeability, is that the junctions formed where three epithelial cells meet (tricellular junctions) control such passage (Krug et al. 2009; Krug et al. 2013). The major component of the tricellular junction is tricellulin (Ikenouchi et al. 2005). In the mouse small intestine, by qRT-PCR, tricellulin (encoded by the Marveld2 gene) was expressed at moderate levels (Table) and the level of its expression was not different in the CF mouse intestine (Fig. 1k). Unfortunately, a suitable antibody was not obtained so neither levels of tricellulin protein expression nor localization could be investigated in the CF intestine.

In contrast to the cytoplasmic relocalization of TJ components in the villus epithelium, the crypt epithelium in the CF intestine had increased claudin-2 immunolocalization at the TJ/ lateral membrane. It is known that the crypts are hypertrophied in the CF intestine (Durie et al. 2004;De Lisle et al. 2007) and the increase in claudin-2 protein levels may be partly explained by this hypertrophy. Claudin- 2 is considered a pore-forming claudin with high 
permeability to $\mathrm{Na}^{+}$(Amasheh et al. 2002). Importantly, luminal $\mathrm{Na}+$ is required for efficient absorption of digested nutrients from the intestinal lumen into the enterocyte (Wada et al. 2012). This is because the uptake of most monosaccharides, amino acids, and peptides is $\mathrm{Na}$-dependent. Also, intestinal absorption of bile acids for their enterohepatic recirculation is $\mathrm{Na}+-$ dependent, and bile acids are required for efficient fat assimilation. Therefore, paracellular recycling of $\mathrm{Na}+$ back into the intestinal lumen is required for efficient intestinal nutrient absorptive function. This is clearly demonstrated by the fact that mice lacking both the Na+-selective pore-forming claudins 2 and 15 in the intestine die of malnutrition (Wada et al. 2012). While nutritional deficits are common in patients with $\mathrm{CF}$ as well as in CF mice, they are not fully understood (De Lisle and Borowitz 2013). Because paracellular secretion of $\mathrm{Na}+$ into the gut lumen is dependent on $\mathrm{Cl}$ - transport through CFTR on enterocyte apical membranes (Gawenis et al. 2004), there will be a deficiency in luminal $\mathrm{Na}+$ in the $\mathrm{CF}$ small intestine. It may be that upregulation of claudin-2 expression is a compensatory response in $\mathrm{CF}$ to enhance paracellular $\mathrm{Na}+$ flux into the lumen.

Several mechanisms have been identified that can lead to increased intestinal permeability, the major ones being various cytokines produced during inflammation, and substances produced by the intestinal microbiota that can directly affect TJs and the cortical actin cytoskeleton of the epithelium (Camilleri et al. 2012). In the CF mouse intestine inflammation results from microbial dysbiosis (De Lisle et al. 2006; Norkina et al. 2004a), which is defined as a change in the composition of the intestinal microbiota from the normal healthy state. Microbial dysbiosis in the CF mouse small intestine takes the form of bacterial overgrowth and is characterized by loss of species richness and diversity, with enrichment of bacterial families including Bacteroidaceae, Mycobacteriaceae, and Pseudonocardiaceae (Lynch et al. 2013). These bacterial families are associated with gastrointestinal infection and with effects on the immune system.

Examination of cytokines known to influence paracellular permeability revealed significantly elevated levels of the pro-inflammatory TNFa and decreased levels of the antiinflammatory IL-10 in the CF mouse intestine. Anti-TNF antibodies are an effective therapy for various inflammatory conditions such as rheumatoid arthritis (Vinay and Kwon 2012) and inflammatory bowel disease (Hering and Schulzke 2009). The use of anti-TNF therapy in $\mathrm{CF}$ is not routine, and in fact there are only three case reports in the literature. In all three reports, anti-TNF therapy was used in patients with $\mathrm{CF}$ to treat comorbidities rather than $\mathrm{CF}$ itself. Two case reports were of patients with CF who also had rheumatoid arthritis (Visser et al. 2012;Casserly and Donat 2009) and one report was of a patient that also had Crohn's disease (Vincenzi et al. 2010). In all three patients, in addition to improving the targeted problem, airway function was also stabilized or improved and there was a decrease in the frequency of airway exacerbations. Remission was achieved for the patient with Crohn's disease, but whether intestinal permeability was also improved in these patients was not addressed. The interpretation of the airway benefits of anti-TNF therapy in CF is that TNF is greatly increased in the infected CF airways and this cytokine has a major role in recruiting neutrophils which is one of the major pathogenic mechanisms of airway tissue damage. In any case, because of the role of TNF in inflammation and increased intestinal permeability, anti-TNF therapy may improve the intestinal barrier and have multifaceted benefits in patients with CF.

Whether microbial dysbiosis in the CF intestine causes increased permeability solely via inflammatory cytokines, or also includes effects of microbial substances from dysbiosis, such as C.perfringens enterotoxin (Takahashi et al. 2005), will require further investigation to determine. 
It is increasingly being recognized that the intestinal barrier has a strong influence on systemic immunity, and impaired barrier function can contribute to pathologies distant from the gut (Ivanov et al. 2009;Penders et al. 2007). Because there is microbial dysbiosis and increased permeability in the $\mathrm{CF}$ intestine, pro-inflammatory microbial products (e.g., lipopolysaccharide) may become systemic and contribute to airway inflammation which is the most serious pathology in CF. Therefore, therapies targeted to improving the mucosal barrier of the intestine may lead to overall health improvement in patients with $\mathrm{CF}$.

\section{Acknowledgments}

I thank Reshana Rampersaud for excellent technical assistance. This work was supported by NIH grant AI 083479 to RCD.

\section{References}

Al-Sadi R, Ye D, Said HM, Ma TY. Cellular and molecular mechanism of interleukin-1beta modulation of Caco-2 intestinal epithelial tight junction barrier. J Cell Mol Med. 2011; 15:970-982. [PubMed: 20406328]

Amasheh S, Meiri N, Gitter AH, Schoeneberg T, Mankertz J, Schulzke JD, Fromm M. Claudin-2 expression induces cation-selective channels in tight junctions of epithelial cells. J Cell Sci. 2002; 115:4969-4976. [PubMed: 12432083]

Amasheh S, Milatz S, Krug SM, Bergs M, Amasheh M, Schulzke JD, Fromm M. Na+ absorption defends from paracellular back-leakage by claudin-8 upregulation. Biochem Biophys Res Commun. 2009; 378:45-50. [PubMed: 19000657]

Anderson JM, Van Itallie CM. Physiology and function of the tight junction. Cold Spring Harb Perspect Biol. 2009; 1:a002584. [PubMed: 20066090]

Barthel LK, Raymond PA. Improved method for obtaining 3- $\mu$ m cryosections for immunocytochemistry. J Histochem Cytochem. 1990; 38:1383-1388. [PubMed: 2201738]

Beaurepaire C, Smyth D, McKay DM. Interferon-gamma regulation of intestinal epithelial permeability. J Interferon Cytokine Res. 2009; 29:133-144. [PubMed: 19196071]

Berglund JJ, Riegler M, Zolotarevsky Y, Wenzl E, Turner JR. Regulation of human jejunal transmucosal resistance and MLC phosphorylation by $\mathrm{Na}(+)$-glucose cotransport. Am J Physiol Gastrointest Liver Physiol. 2001; 281:G1487-G1493. [PubMed: 11705754]

Bruewer M, Luegering A, Kucharzik T, Parkos CA, Madara JL, Hopkins AM, Nusrat A. Proinflammatory cytokines disrupt epithelial barrier function by apoptosis-independent mechanisms. J Immunol. 2003; 171:6164-6172. [PubMed: 14634132]

Camilleri M, Madsen K, Spiller R, Greenwood-Van MB, Verne GN. Intestinal barrier function in health and gastrointestinal disease. Neurogastroenterol Motil. 2012; 24:503-512. [PubMed: 22583600]

Casserly B, Donat W. Stabilization of lung function and clinical symptoms in a patient with cystic fibrosis (CF) after institution of infliximab: a monoclonal antibody that binds tumor necrosis factor alpha. Lung. 2009; 187:149-152. [PubMed: 19247707]

Castellani S, Guerra L, Favia M, Di GS, Casavola V, Conese M. NHERF1 and CFTR restore tight junction organisation and function in cystic fibrosis airway epithelial cells: role of ezrin and the RhoA/ROCK pathway. Lab Invest. 2012; 92:1527-1540. [PubMed: 22964850]

Cesarone CF, Bolognesi C, Santi L. Improved microfluorometric DNA determination in biological material using 33258 Hoechst. Anal Biochem. 1979; 100:188-197. [PubMed: 94515]

De Lisle RC, Borowitz D. The Cystic Fibrosis Intestine. Cold Spring Harb Perspect Med. 2013

De Lisle RC, Mueller R, Boyd M. Impaired mucosal barrier function in the small intestine of the cystic fibrosis mouse. J Pediatr Gastroenterol Nutr. 2011; 53:371-379. [PubMed: 21970994]

De Lisle RC, Roach E, Jansson K. Effects of laxative and N-acetylcysteine on mucus accumulation, bacterial load, transit, and inflammation in the cystic fibrosis mouse small intestine. Am J Physiol Gastrointest Liver Physiol. 2007; 293:G577-G584. [PubMed: 17615175] 
De Lisle RC, Roach EA, Norkina O. Eradication of small intestinal bacterial overgrowth in the cystic fibrosis mouse reduces mucus accumulation. J Pediatr Gastroenterol Nutr. 2006; 42:46-52. [PubMed: 16385253]

Denizot J, Sivignon A, Barreau F, Darcha C, Chan HF, Stanners CP, Hofman P, rfeuille-Michaud A, Barnich N. Adherent-invasive Escherichia coli induce claudin-2 expression and barrier defect in CEABAC10 mice and Crohn's disease patients. Inflamm Bowel Dis. 2012; 18:294-304. [PubMed: 21688348]

Ding L, Lu Z, Foreman O, Tatum R, Lu Q, Renegar R, Cao J, Chen YH. Inflammation and disruption of the mucosal architecture in claudin-7-deficient mice. Gastroenterology. 2012; 142:305-315. [PubMed: 22044670]

Drozdowski LA, Thomson AB. Intestinal sugar transport. World J Gastroenterol. 2006; 12:1657-1670. [PubMed: 16586532]

Durie PR, Kent G, Phillips MJ, Ackerley CA. Characteristic multiorgan pathology of cystic fibrosis in a long-living cystic fibrosis transmembrane regulator knockout murine model. Am J Pathol. 2004; 164:1481-1493. [PubMed: 15039235]

Eckman EA, Cotton CU, Kube DM, Davis PB. Dietary changes improve survival of CFTR S489X homozygous mutant mouse. Am J Physiol Lung Cell Mol Physiol. 1995; 269:L625-L630.

Fanning AS, Jameson BJ, Jesaitis LA, Anderson JM. The tight junction protein ZO-1 establishes a link between the transmembrane protein occludin and the actin cytoskeleton. J Biol Chem. 1998; 273:29745-29753. [PubMed: 9792688]

Fanning AS, Van Itallie CM, Anderson JM. Zonula occludens-1 and -2 regulate apical cell structure and the zonula adherens cytoskeleton in polarized epithelia. Mol Biol Cell. 2012; 23:577-590. [PubMed: 22190737]

Fujita H, Chiba H, Yokozaki H, Sakai N, Sugimoto K, Wada T, Kojima T, Yamashita T, Sawada N. Differential expression and subcellular localization of claudin-7, $-8,-12,-13$, and -15 along the mouse intestine. J Histochem Cytochem. 2006; 54:933-944. [PubMed: 16651389]

Furuse M, Hirase T, Itoh M, Nagafuchi A, Yonemura S, Tsukita S, Tsukita S. Occludin: a novel integral membrane protein localizing at tight junctions. J Cell Biol. 1993; 123:1777-1788. [PubMed: 8276896]

Gawenis LR, Hut H, Bot AGM, Shull GE, De Jonge HR, Stien X, Miller ML, Clarke LL. Electroneutral sodium absorption and electrogenic anion secretion across murine small intestine are regulated in parallel. Am J Physiol Gastrointest Liver Physiol. 2004; 287:G1140-G1149. [PubMed: 15284023]

Gunzel D, Yu AS. Claudins and the modulation of tight junction permeability. Physiol Rev. 2013; 93:525-569. [PubMed: 23589827]

Guttman JA, Finlay BB. Tight junctions as targets of infectious agents. Biochim Biophys Acta. 2009; 1788:832-841. [PubMed: 19059200]

Hallberg K, Grzegorczyk A, Larson G, Strandvik B. Intestinal permeability in cystic fibrosis in relation to genotype. J Pediatr Gastroenterol Nutr. 1997; 25:290-295. [PubMed: 9285379]

Hering NA, Schulzke JD. Therapeutic options to modulate barrier defects in inflammatory bowel disease. Dig Dis. 2009; 27:450-454. [PubMed: 19897959]

Ikenouchi J, Furuse M, Furuse K, Sasaki H, Tsukita S, Tsukita S. Tricellulin constitutes a novel barrier at tricellular contacts of epithelial cells. J Cell Biol. 2005; 171:939-945. [PubMed: 16365161]

Ivanov II, Atarashi K, Manel N, Brodie EL, Shima T, Karaoz U, Wei D, Goldfarb KC, Santee CA, Lynch SV, Tanoue T, Imaoka A, Itoh K, Takeda K, Umesaki Y, Honda K, Littman DR. Induction of intestinal Th17 cells by segmented filamentous bacteria. Cell. 2009; 139:485-498. [PubMed: 19836068]

John LJ, Fromm M, Schulzke JD. Epithelial barriers in intestinal inflammation. Antioxid Redox Signal. 2011; 15:1255-1270. [PubMed: 21294654]

Krug SM, Amasheh M, Dittmann I, Christoffel I, Fromm M, Amasheh S. Sodium caprate as an enhancer of macromolecule permeation across tricellular tight junctions of intestinal cells. Biomaterials. 2013; 34:275-282. [PubMed: 23069717] 
Krug SM, Amasheh S, Richter JF, Milatz S, Gunzel D, Westphal JK, Huber O, Schulzke JD, Fromm M. Tricellulin forms a barrier to macromolecules in tricellular tight junctions without affecting ion permeability. Mol Biol Cell. 2009; 20:3713-3724. [PubMed: 19535456]

Lameris AL, Huybers S, Kaukinen K, Makela TH, Bindels RJ, Hoenderop JG, Nevalainen PI. Expression profiling of claudins in the human gastrointestinal tract in health and during inflammatory bowel disease. Scand J Gastroenterol. 2013; 48:58-69. [PubMed: 23205909]

Laukoetter MG, Nava P, Lee WY, Severson EA, Capaldo CT, Babbin BA, Williams IR, Koval M, Peatman E, Campbell JA, Dermody TS, Nusrat A, Parkos CA. JAM-A regulates permeability and inflammation in the intestine in vivo. J Exp Med. 2007; 204:3067-3076. [PubMed: 18039951]

Lynch SV, Goldfarb KC, Wild Y, Kong W, De Lisle RC, Brodie EL. Cystic fibrosis transmembrane conductance regulator knockout mice exhibit aberrant gastrointestinal microbiota. Gut Microbes. 2013; 4:41-47. [PubMed: 23060053]

Markov AG, Veshnyakova A, Fromm M, Amasheh M, Amasheh S. Segmental expression of claudin proteins correlates with tight junction barrier properties in rat intestine. J Comp Physiol B. 2010; 180:591-598. [PubMed: 20049600]

Mashukova A, Wald FA, Salas PJ. Tumor necrosis factor alpha and inflammation disrupt the polarity complex in intestinal epithelial cells by a posttranslational mechanism. Mol Cell Biol. 2011; 31:756-765. [PubMed: 21135124]

Mazzon E, Cuzzocrea S. Role of TNF-alpha in ileum tight junction alteration in mouse model of restraint stress. Am J Physiol Gastrointest Liver Physiol. 2008; 294:G1268-G1280. [PubMed: 18308862]

Milatz S, Krug SM, Rosenthal R, Gunzel D, Muller D, Schulzke JD, Amasheh S, Fromm M. Claudin-3 acts as a sealing component of the tight junction for ions of either charge and uncharged solutes. Biochim Biophys Acta. 2010; 1798:2048-2057. [PubMed: 20655293]

Norkina O, Burnett TG, De Lisle RC. Bacterial overgrowth in the cystic fibrosis transmembrane conductance regulator null mouse small intestine. Infect Immun. 2004a; 72:6040-6049. [PubMed: 15385508]

Norkina O, Kaur S, Ziemer D, De Lisle RC. Inflammation of the cystic fibrosis mouse small intestine. Am J Physiol Gastrointest Liver Physiol. 2004b; 286:G1032-G1041. [PubMed: 14739145]

Notterpek L, Roux KJ, Amici SA, Yazdanpour A, Rahner C, Fletcher BS. Peripheral myelin protein 22 is a constituent of intercellular junctions in epithelia. Proc Natl Acad Sci U S A. 2001; 98:1440414409. [PubMed: 11717414]

Patel RM, Myers LS, Kurundkar AR, Maheshwari A, Nusrat A, Lin PW. Probiotic bacteria induce maturation of intestinal claudin 3 expression and barrier function. Am J Pathol. 2012; 180:626635. [PubMed: 22155109]

Penders J, Stobberingh EE, van den Brandt PA, Thijs C. The role of the intestinal microbiota in the development of atopic disorders. Allergy. 2007; 62:1223-1236. [PubMed: 17711557]

Poritz LS, Harris LR III, Kelly AA, Koltun WA. Increase in the tight junction protein claudin-1 in intestinal inflammation. Dig Dis Sci. 2011; 56:2802-2809. [PubMed: 21748286]

Rahner C, Mitic LL, Anderson JM. Heterogeneity in expression and subcellular localization of claudins 2, 3, 4, and 5 in the rat liver, pancreas, and gut. Gastroenterology. 2001; 120:411-422. [PubMed: 11159882]

Rodgers LS, Beam MT, Anderson JM, Fanning AS. Epithelial barrier assembly requires coordinated activity of multiple domains of the tight junction protein ZO-1. J Cell Sci. 2013; 126:1565-1575. [PubMed: 23418357]

Roux KJ, Amici SA, Fletcher BS, Notterpek L. Modulation of epithelial morphology, monolayer permeability, and cell migration by growth arrest specific 3/peripheral myelin protein 22. Mol Biol Cell. 2005; 16:1142-1151. [PubMed: 15635102]

Snouwaert JN, Brigman KK, Latour AM, Malouf NN, Boucher RC, Smithies O, Koller BH. An animal model for cystic fibrosis made by gene targeting. Science. 1992; 257:1083-1088. [PubMed: 1380723]

Stallings VA, Stark LJ, Robinson KA, Feranchak AP, Quinton H. Evidence-based practice recommendations for nutrition-related management of children and adults with cystic fibrosis and 
pancreatic insufficiency: results of a systematic review. J Am Diet Assoc. 2008; 108:832-839. [PubMed: 18442507]

Stevenson BR, Siliciano JD, Mooseker MS, Goodenough DA. Identification of ZO-1: a high molecular weight polypeptide associated with the tight junction (zonula occludens) in a variety of epithelia. J Cell Biol. 1986; 103:755-766. [PubMed: 3528172]

Sun X, Yang H, Nose K, Nose S, Haxhija EQ, Koga H, Feng Y, Teitelbaum DH. Decline in intestinal mucosal IL-10 expression and decreased intestinal barrier function in a mouse model of total parenteral nutrition. Am J Physiol Gastrointest Liver Physiol. 2008; 294:G139-G147. [PubMed: 17991705]

Suzuki T, Yoshinaga N, Tanabe S. Interleukin-6 (IL-6) regulates claudin-2 expression and tight junction permeability in intestinal epithelium. J Biol Chem. 2011; 286:31263-31271. [PubMed: 21771795]

Takahashi A, Kondoh M, Masuyama A, Fujii M, Mizuguchi H, Horiguchi Y, Watanabe Y. Role of Cterminal regions of the C-terminal fragment of Clostridium perfringens enterotoxin in its interaction with claudin-4. J Control Release. 2005; 108:56-62. [PubMed: 16091298]

Tamura A, Kitano Y, Hata M, Katsuno T, Moriwaki K, Sasaki H, Hayashi H, Suzuki Y, Noda T, Furuse M, Tsukita S, Tsukita S. Megaintestine in claudin-15-deficient mice. Gastroenterology. 2008; 134:523-534. [PubMed: 18242218]

Timmerman V, Nelis E, Van HW, Nieuwenhuijsen BW, Chen KL, Wang S, Ben OK, Cullen B, Leach RJ, Hanemann CO. The peripheral myelin protein gene PMP-22 is contained within the CharcotMarie-Tooth disease type 1A duplication. Nat Genet. 1992; 1:171-175. [PubMed: 1303230]

van Elburg RM, Uil JJ, Van Aalderen WM, Mulder CJ, Heymans HS. Intestinal permeability in exocrine pancreatic insufficiency due to cystic fibrosis or chronic pancreatitis. Pediatr Res. 1996; 39:985-991. [PubMed: 8725259]

Van Itallie CM, Anderson JM. Claudins and Epithelial Paracellular Transport. Annu Rev Physiol. 2006; 68:403-429. [PubMed: 16460278]

Vinay DS, Kwon BS. Targeting TNF superfamily members for therapeutic intervention in rheumatoid arthritis. Cytokine. 2012; 57:305-312. [PubMed: 22209079]

Vincenzi F, Bizzarri B, Ghiselli A, de' AN, Fornaroli F, de' Angelis GL. Cystic fibrosis and Crohn's disease: successful treatment and long term remission with infliximab. World J Gastroenterol. 2010; 16:1924-1927. [PubMed: 20397273]

Visser S, Martin M, Serisier DJ. Improvements in cystic fibrosis lung disease and airway inflammation associated with etanercept therapy for rheumatoid arthritis: a case report. Lung. 2012; 190:579_ 581. [PubMed: 22660986]

Wada M, Tamura A, Takahashi N, Tsukita S. Loss of Claudins 2 and 15 From Mice Causes Defects in Paracellular $\mathrm{Na}(+)$ Flow and Nutrient Transport in Gut and Leads to Death from Malnutrition. Gastroenterology. 2012; 144:369-380. [PubMed: 23089202]

Watson CJ, Hoare CJ, Garrod DR, Carlson GL, Warhurst G. Interferon-gamma selectively increases epithelial permeability to large molecules by activating different populations of paracellular pores. J Cell Sci. 2005; 118:5221-5230. [PubMed: 16249235]

Watson CJ, Rowland M, Warhurst G. Functional modeling of tight junctions in intestinal cell monolayers using polyethylene glycol oligomers. Am J Physiol Cell Physiol. 2001; 281:C388C397. [PubMed: 11443038]

Werlin SL, uri-Silbiger I, Kerem E, Adler SN, Goldin E, Zimmerman J, Malka N, Cohen L, Armoni S, Yatzkan-Israelit Y, Bergwerk A, Aviram M, Bentur L, Mussaffi H, Bjarnasson I, Wilschanski M. Evidence of Intestinal Inflammation in Patients With Cystic Fibrosis. J Pediatr Gastroenterol Nutr. 2010; 51:304-308. [PubMed: 20512061]

Zeissig S, Burgel N, Gunzel D, Richter J, Mankertz J, Wahnschaffe U, Kroesen AJ, Zeitz M, Fromm M, Schulzke JD. Changes in expression and distribution of claudin 2, 5 and 8 lead to discontinuous tight junctions and barrier dysfunction in active Crohn's disease. Gut. 2007; 56:6172. [PubMed: 16822808] 


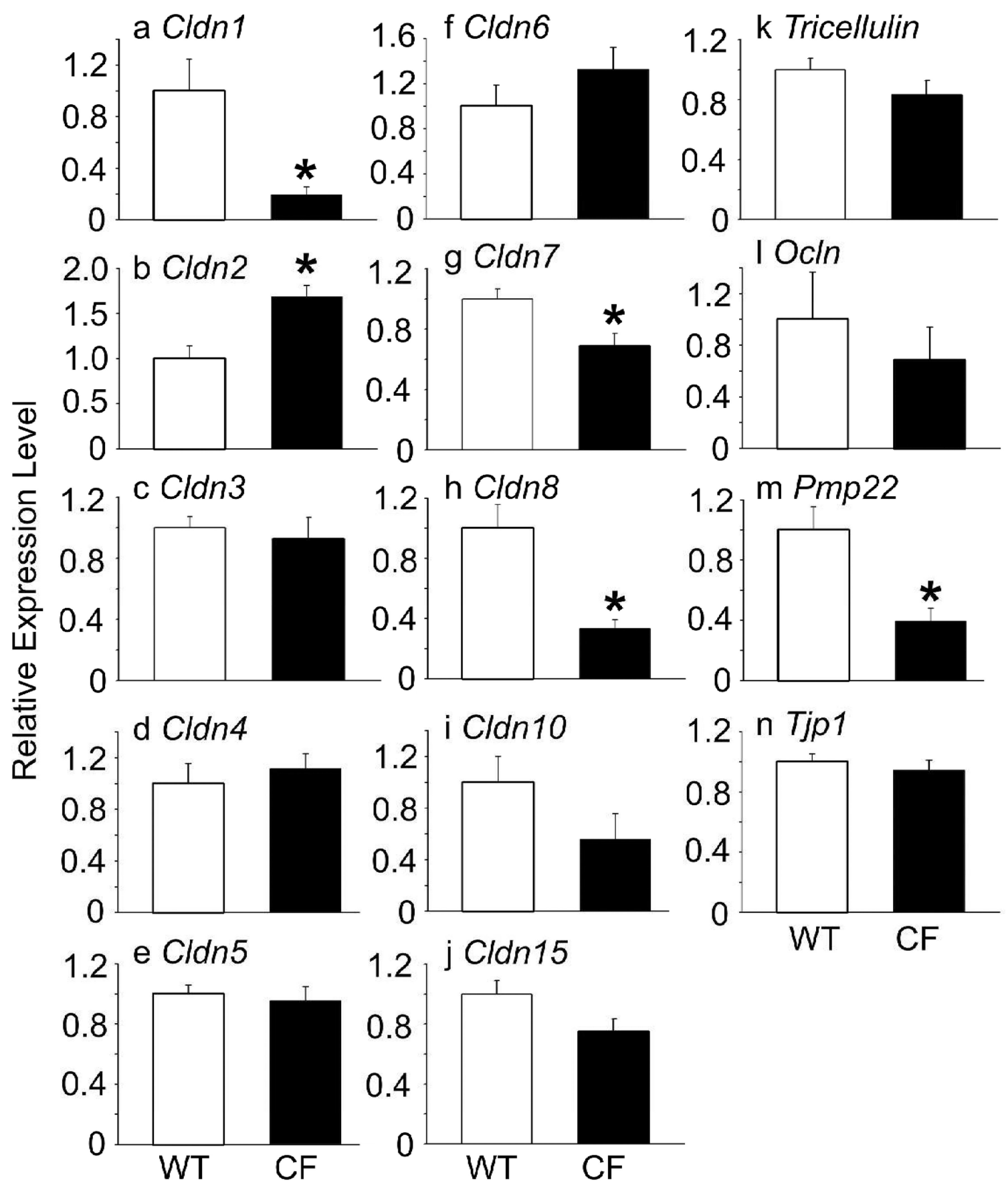

Fig. 1.

Gene expression levels of TJ components in CF as compared to WT small intestine. Total RNA from the entire small intestine of WT and CF mice was used for quantitative RT-PCR (see Methods and Table). (a) Cldn1; (b) Cldn2; (c) Cldn3; (d) Cldn4; (e) Cldn5; (f) Cldn6; (g) Cldn7; (h) Cldn8; (i) Cldn10; (j) Cldn15; (k) Tricellulin (Marveld2); (1) Ocln; (m) Pmp22; (n) Tjp1 (ZO-1). Data were normalized to the mRNA for Rpl26 (ribosomal protein 26 ), fold changes were calculated by the)) $C_{t}$ method, and data were corrected for differential PCR efficiencies. The data are expressed relative to WT set to unity. $(*: P<0.05)$ (n=10 WT and 10 CF samples) 


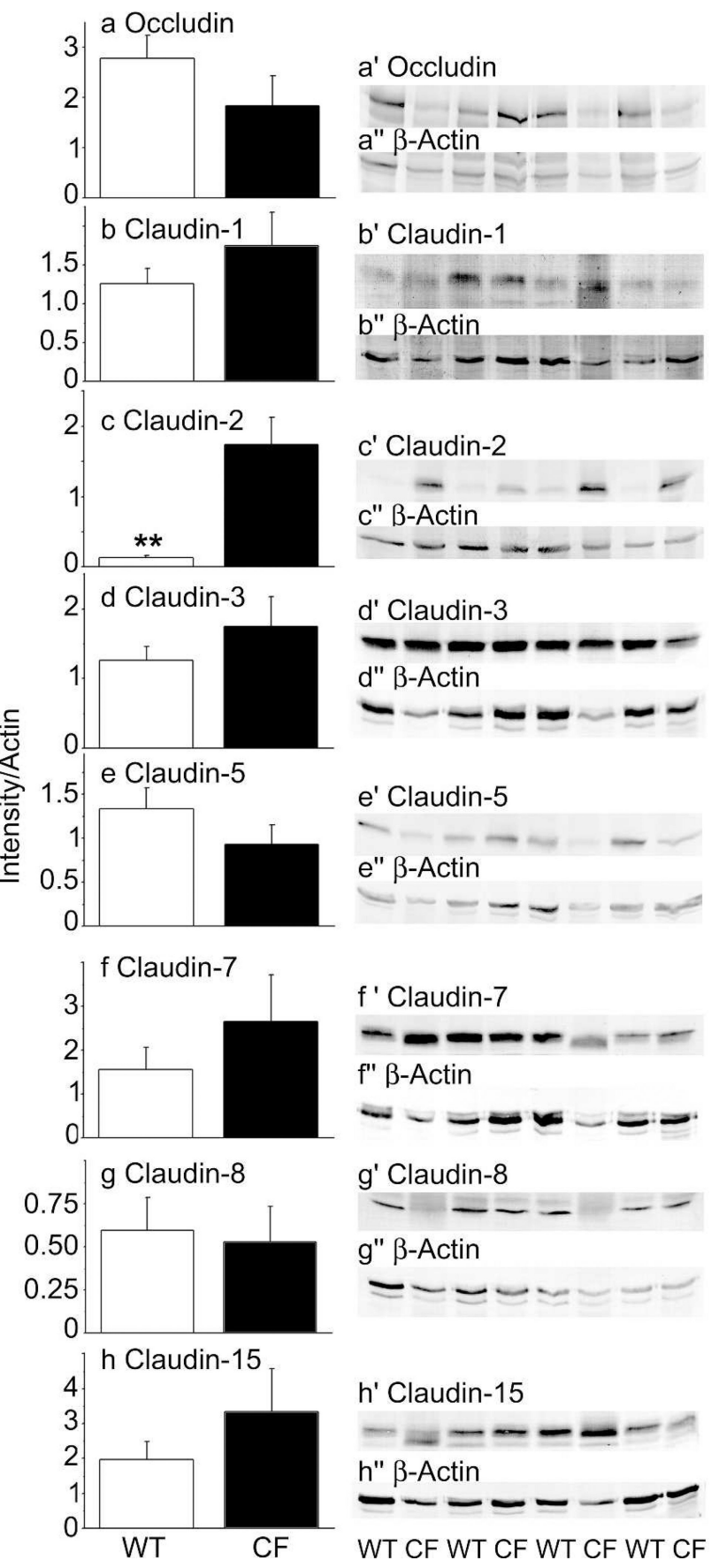

Fig. 2.

Western blot quantification of $\mathrm{TJ}$ proteins in the proximal ileum of the CF as compared to WT small intestine. Homogenates of proximal ileum were separated on SDS-PAGE, transferred to PVDF membranes, and probed with antibodies against the indicated TJ proteins followed by $\beta$-actin. Dried blots were scanned to measure intensity levels to calculate TJ protein levels relative to $\beta$-actin (a" - h"). (a, a') Occludin; (b, b') Claudin-1; (c, c') Claudin-2; (d, d') Claudin-3; (e,e') Claudin-5; (f, f') Claudin-7; (g, g') Claudin-8; (h, h') Claudin-15. (*: $P<0.05 ; \mathrm{n}=4 \mathrm{WT}$ and $4 \mathrm{CF}$ samples) 

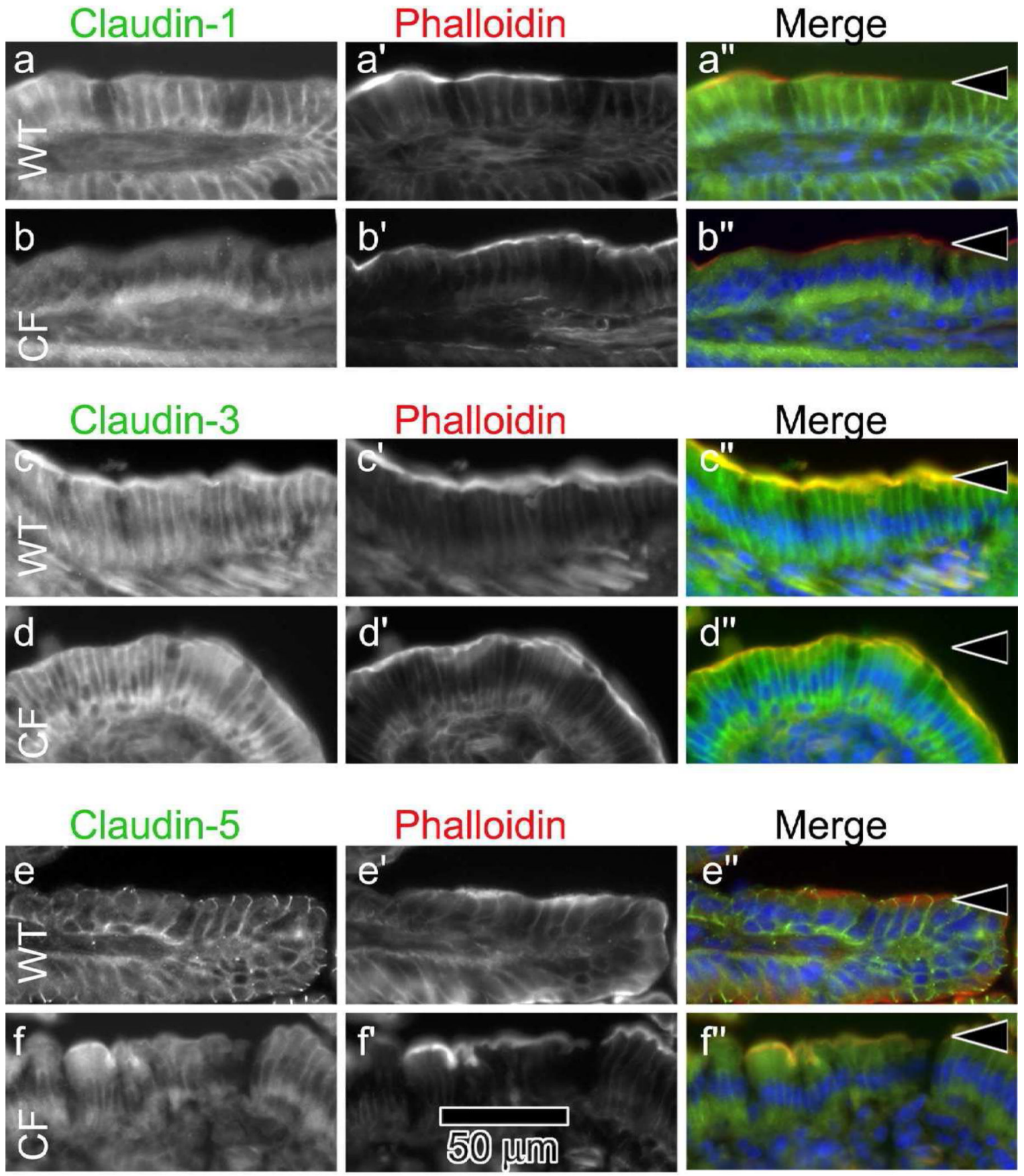

Fig. 3.

Localization of claudin-1, claudin-3, and claudin-5 proteins in CF as compared to WT proximal ileum by indirect immunofluorescence. Cryosections ( $5: \mathrm{m})$ of proximal ileum were stained using the indicated antibodies against TJ proteins followed by FITC-secondary antibody (green, a-f), plus Texas Red phalloidin for the F-actin cortical cytoskeleton (red, $\left.a^{\prime}-f^{\prime}\right)$, and DAPI for nuclei (blue in the Merged panels a"-f"). (a, c, e) WT; (b, d, f) CF). (a,

b) Claudin-1; (c, d) Claudin-3; (e, f) Claudin-5. The imaged areas are in the villus epithelium. Representative of $4 \mathrm{WT}$ and $4 \mathrm{CF}$ mice. 

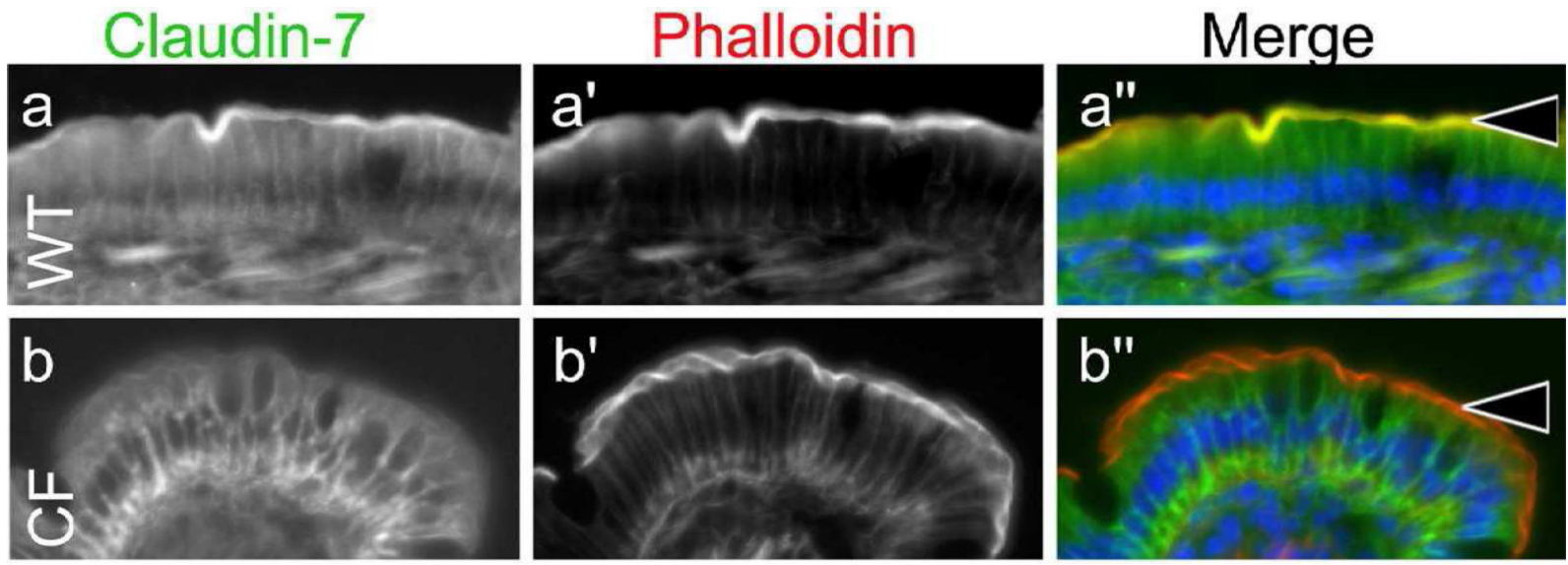

\section{Claudin-8}

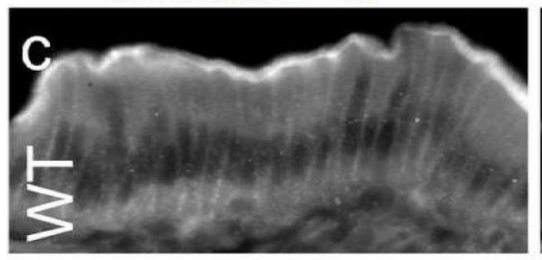

\section{Phalloidin}

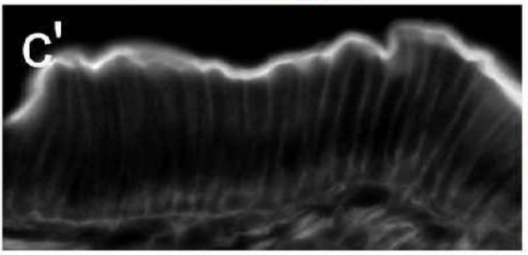

Merge
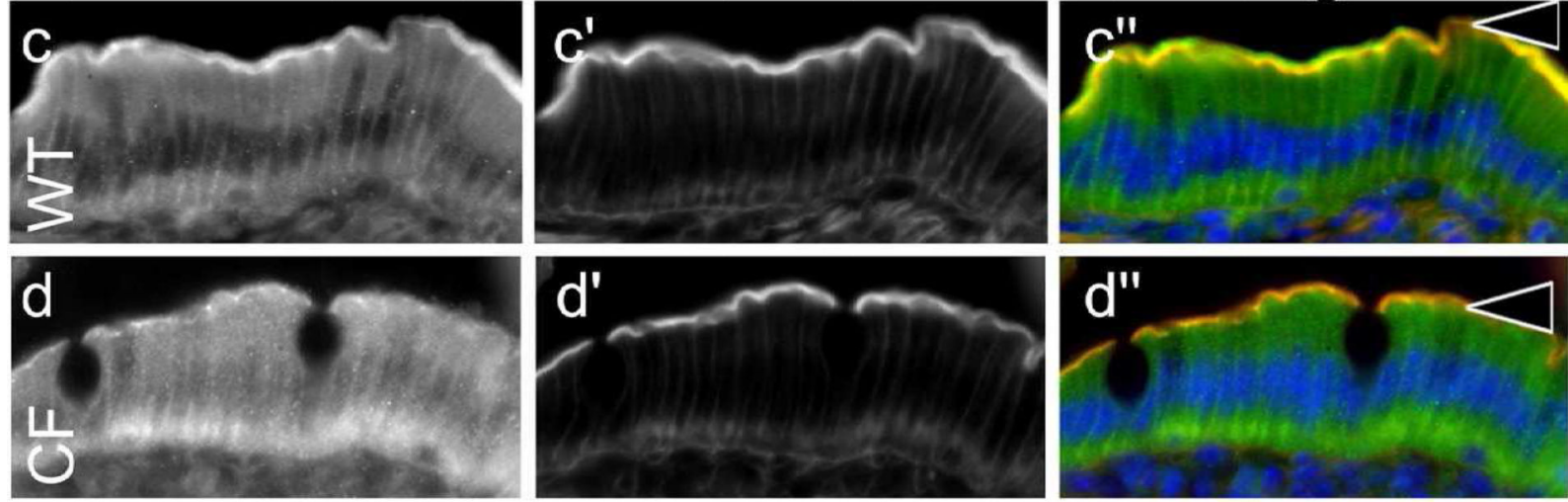

Occludin

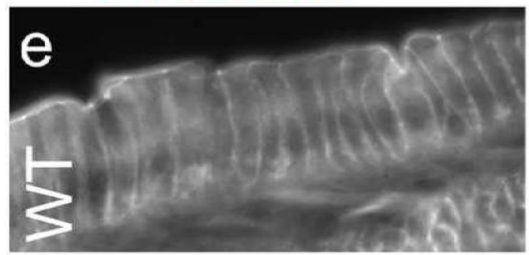

Phalloidin
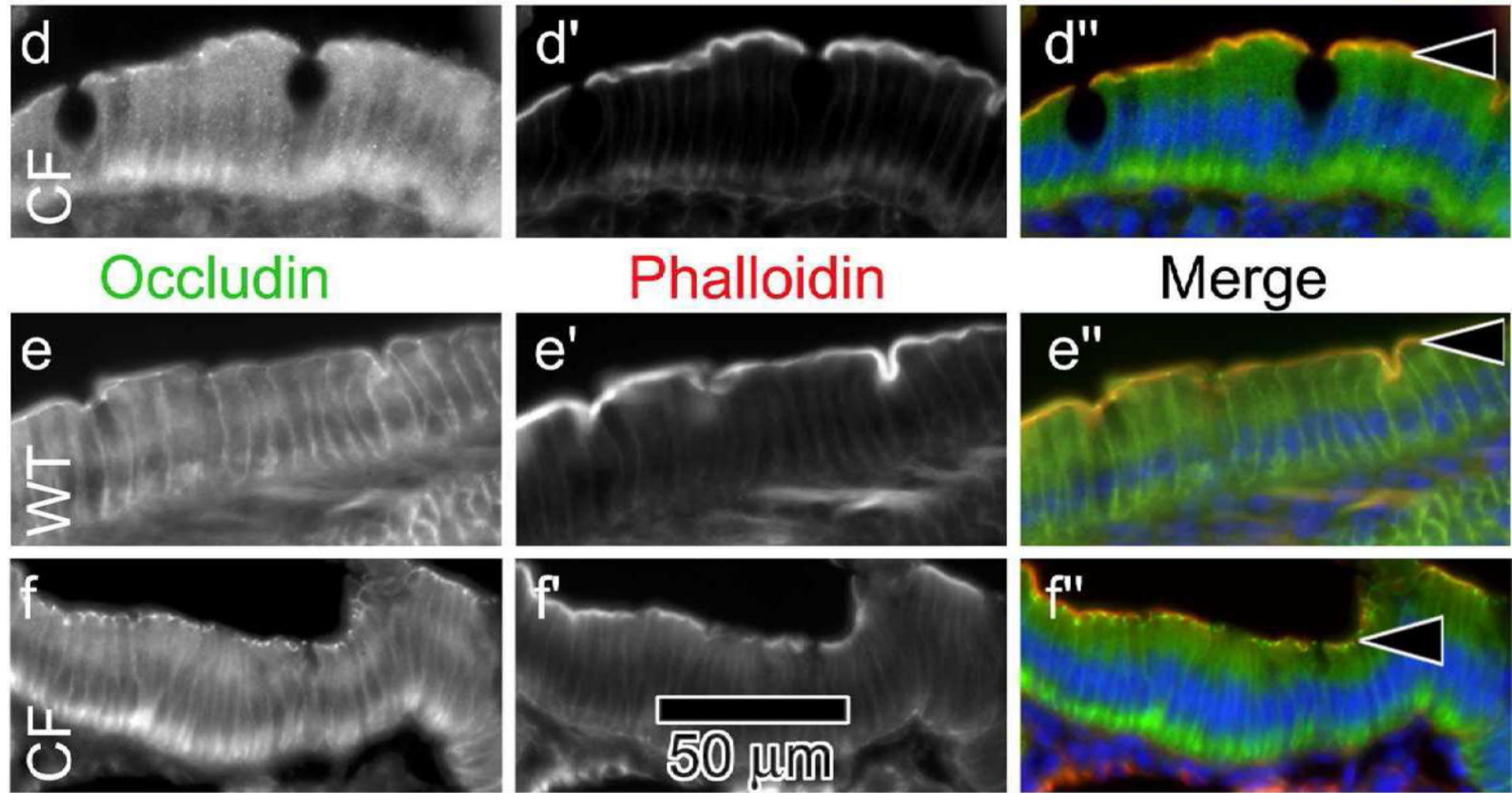

Merge
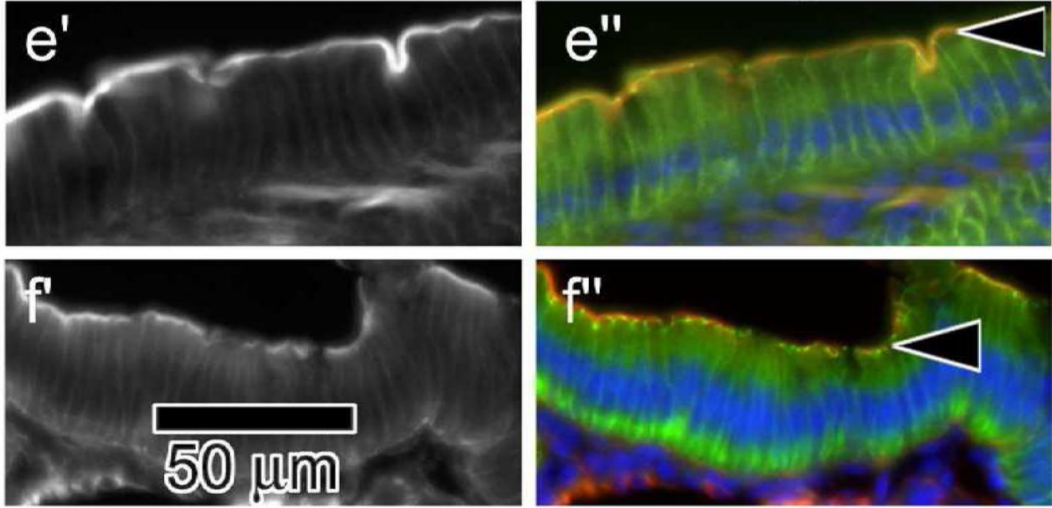

Fig. 4.

Localization of claudin-7 claudin- 8 , and occludin proteins in CF as compared to WT proximal ileum by indirect immunofluorescence. Cryosections ( $5: \mathrm{m})$ of proximal ileum were stained using the indicated antibodies against TJ proteins followed by FITC-secondary antibody (green, a-f), plus Texas Red phalloidin for the F-actin cortical cytoskeleton (red, $\left.a^{\prime} f^{\prime}\right)$, and DAPI for nuclei (blue in the Merged panels a"f"). (a, c, e) WT; (b, d, f) CF). (a, b) Claudin-7; (c, d) Claudin-8; (e, f) Occludin. The imaged areas are in the villus epithelium. Representative of $4 \mathrm{WT}$ and $4 \mathrm{CF}$ mice. 
Claudin-2
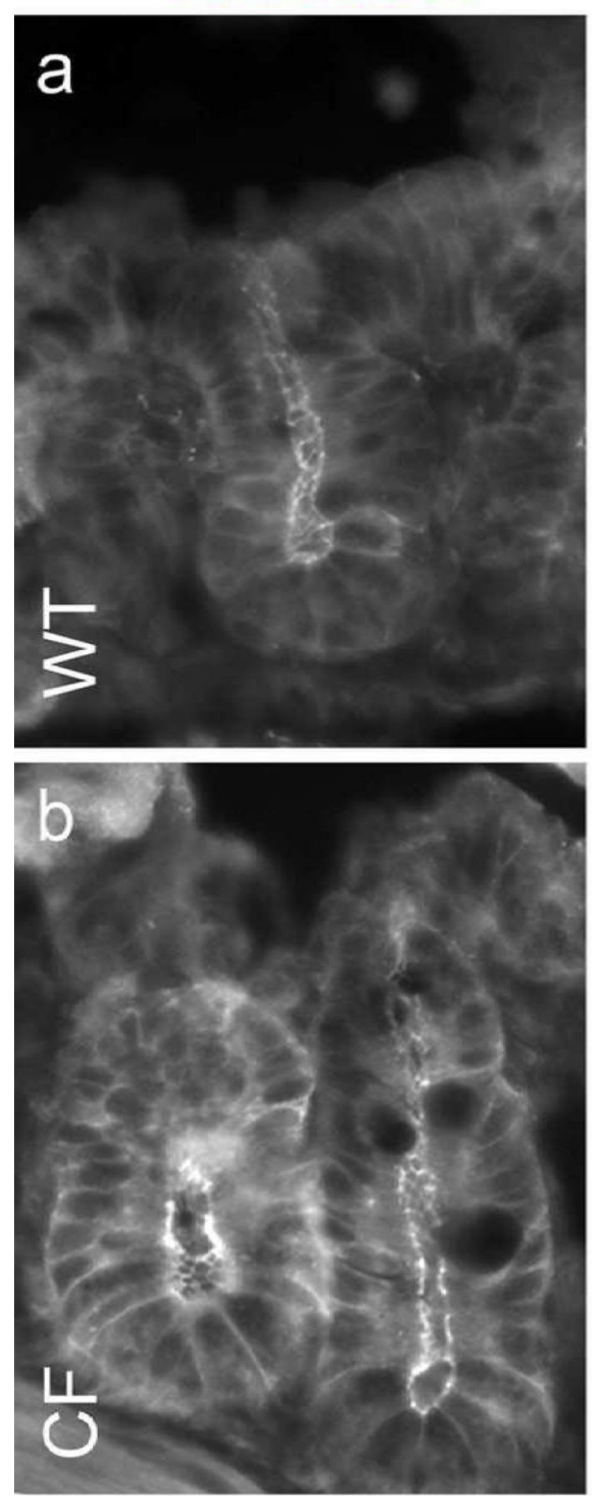

Phalloidin
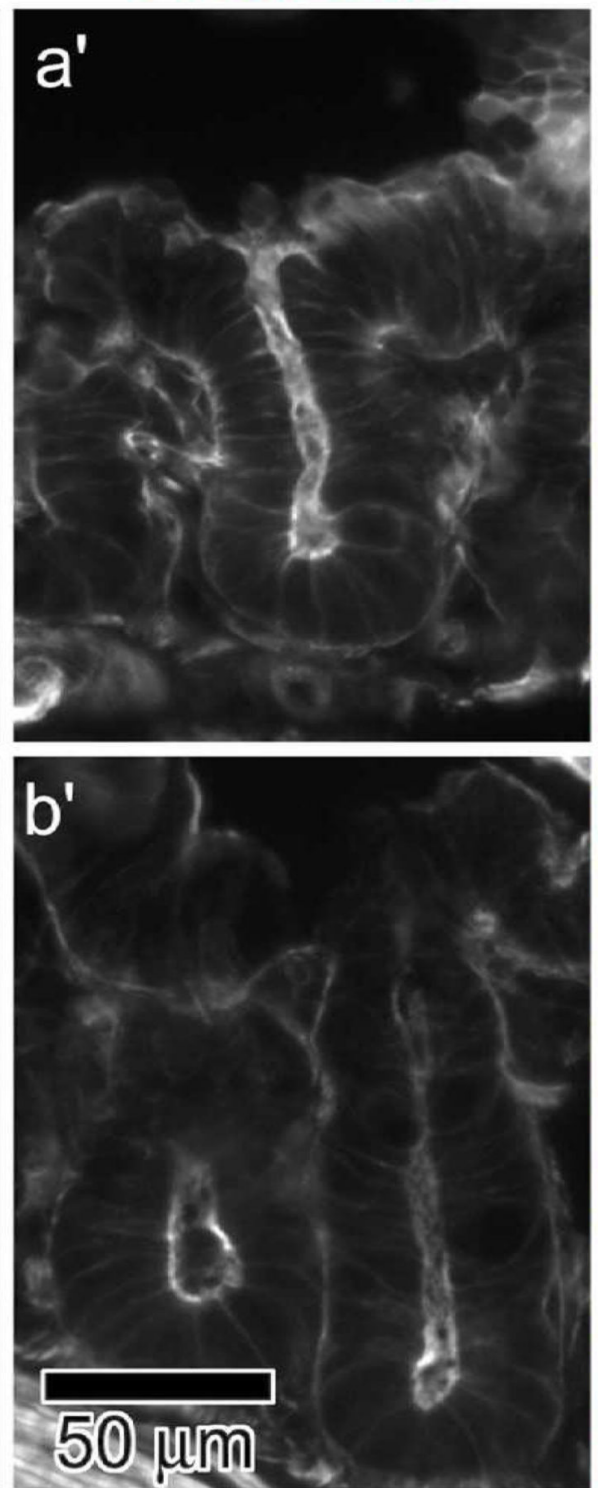

Merge
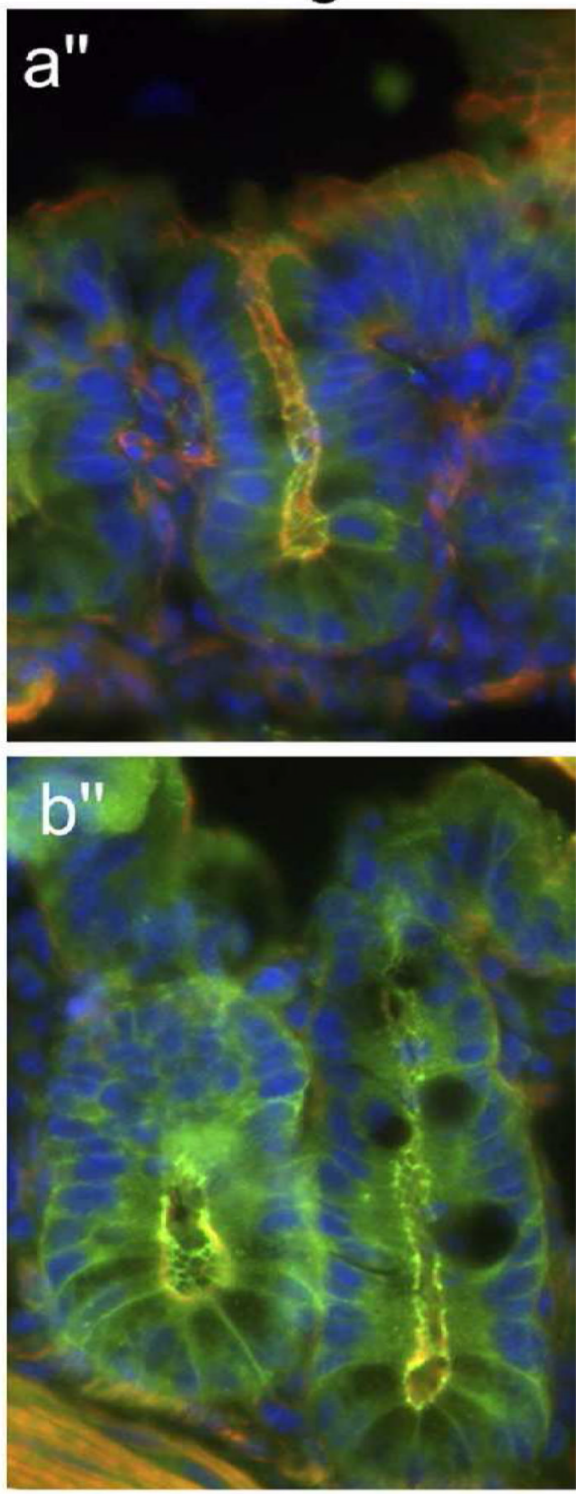

Fig. 5.

Localization of claudin-2 protein in CF as compared to WT proximal ileum by indirect immunofluorescence. Cryosections ( $5 \mathrm{:m}$ ) of proximal ileum were stained using the indicated antibodies against TJ proteins followed by FITC-secondary antibody (green, a-b), plus Texas Red phalloidin for the F-actin cortical cytoskeleton (red, $a^{\prime}-b^{\prime}$ ), and DAPI for nuclei (blue in the Merged panels a"-b"). (a) WT; (b) CF). The imaged areas are in the crypt epithelium. Representative of 4 WT and 4 CF mice. 


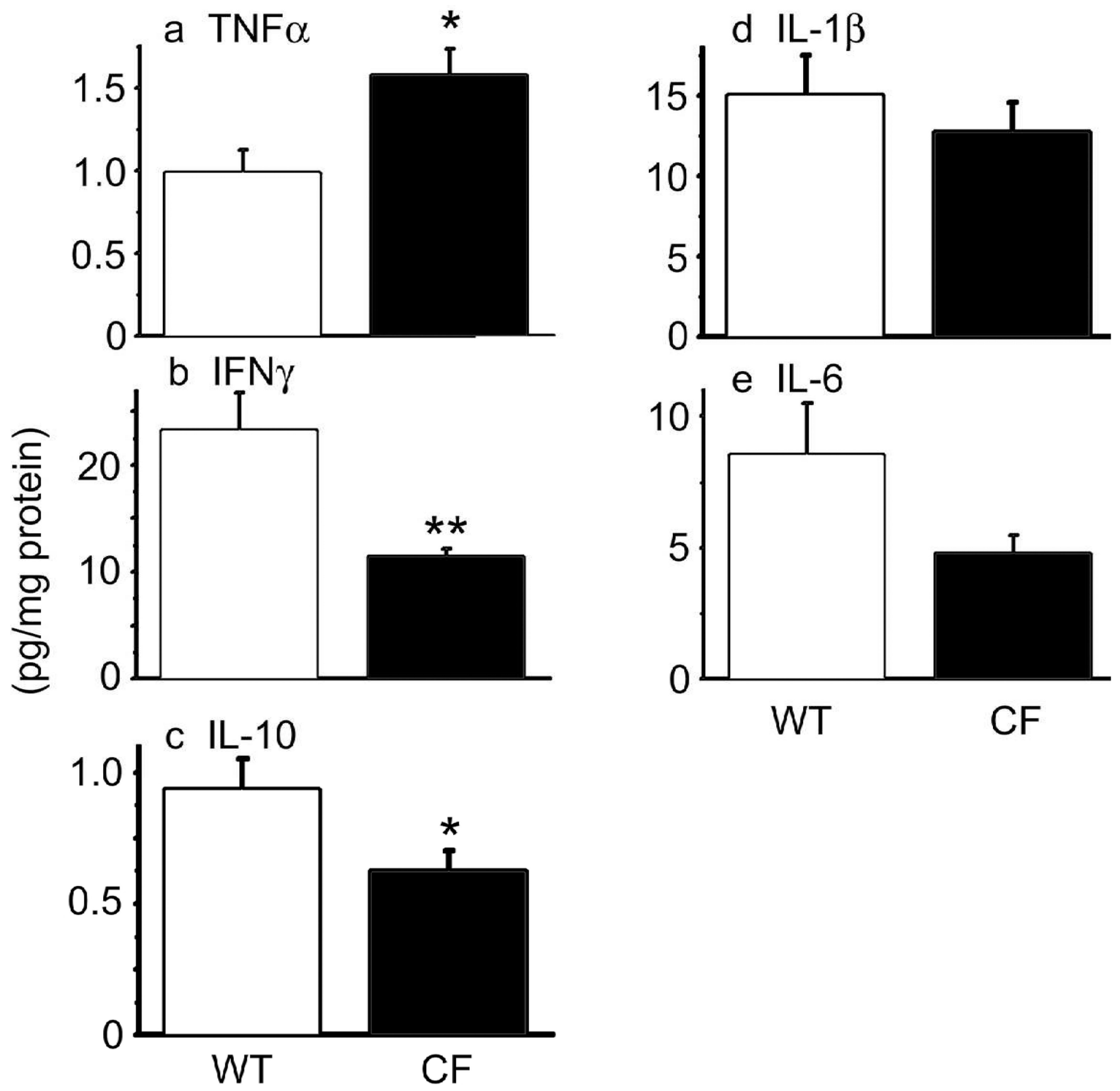

Fig. 6.

Measurement of cytokine levels in CF as compared to WT small intestine. Tissue homogenates were prepared and processed for Luminex analysis of the indicated cytokines (see Methods). (a) TNFa; (b) IFN $\gamma$; (c) IL-10; (d) IL-1 $\beta$; (e) IL-6. (n=6 WT and 7 CF samples; *: $P<0.05)$ 
Table

qRT-PCR Primers

\begin{tabular}{|c|c|c|c|c|}
\hline mRNA & Forward & Reverse & $\mathbf{C}_{\mathbf{t}}$ & bp \\
\hline Ocln & TCCGTGAGGCCTTTTGAA & GGTGCATAATGATTGGGTTTG & 31.3 & 68 \\
\hline Tjp1 & CGCGGAGAGAGACAAGATGT & AGCGTCACTGTGTGCTGTTC & 17.8 & 93 \\
\hline Cldn1 & CTTGACCCCCATCAATGC & CACCTCCCAGAAGGCAGA & 29.7 & 86 \\
\hline Cldn2 & TGAACACGGACCACTGAAAG & TTAGCAGGAAGCTGGGTCAG & 21.5 & 61 \\
\hline Cldn3 & GCAAGCAGACTGTGTGTCGT & TACCGTCACCACTACCAGCA & 24.0 & 110 \\
\hline Cldn4 & GAGGGCTGGGGACCTAGA & GCAAGACAGTGCGGAAAAG & 27.6 & 60 \\
\hline Cldn5 & ACGGGAGGAGCGCTTTAC & GTTGGCGAACCAGCAGAG & 23.1 & 66 \\
\hline Cldn6 & TATCCTGTCCCAGTCCCAAG & GTGCGTCTGTCCTGTGAGTTAC & 29.4 & 62 \\
\hline Cldn7 & GCTAAGAAGCCCAACACCAG & TGCAAAATGTACGACTCGGT & 20.8 & 92 \\
\hline Cldn8 & GTGGATGTGGCCCTAAAGC & CGCTGTGGTCCAGCCTAT & 27.7 & 60 \\
\hline Cldn10 & TGATCCTCTTTATATGGAGCAAAAG & AGAAGCTCCTGCCCATCC & 28.8 & 70 \\
\hline Cldn15 & CCTAGAAAGAGGCCCAGGAA & ACTGCTGGGACTTTCCGTC & 23.3 & 106 \\
\hline Tricellulin (Marveld2) & TTCCAGAAACGAAGGGTCAT & AGGCTCCCACATCATTCTGA & 26.7 & 99 \\
\hline Pmp22 & AGCTGTCCCTTTGAACTGAAAC & CCCCAACAAGAGTAGGAGCA & 19.7 & 84 \\
\hline Rpl26 & AATGGCACAACCGTCCAC & CTTGTCGGGACTTGGCTTT & 18.4 & 112 \\
\hline
\end{tabular}

$\mathrm{C}_{\mathrm{t}}$ values are from primer characterizations using $\sim 10 \mathrm{ng}$ of total RNA in the qRT-PCR reaction and indicate relative mRNA expression levels in the WT small intestine. 